1992

\title{
Fatal Assumption: A Critical Evaluation of the Role of Counsel in Mental Disability Cases
}

Michael L. Perlin

New YorkLaw School, michael.perlin@nyls.edu

Follow this and additional works at: https://digitalcommons.nyls.edu/fac_articles_chapters

Part of the Disability Law Commons, Fourteenth Amendment Commons, Law and Psychology Commons, and the Legal Profession Commons

\section{Recommended Citation}

16 Law and Human Behavior 39-59 (1992)

This Article is brought to you for free and open access by the Faculty Scholarship at DigitalCommons@NYLS. It has been accepted for inclusion in Articles \& Chapters by an authorized administrator of DigitalCommons@NYLS. 


\title{
Fatal Assumption
}

\section{A Critical Evaluation of the Role of Counsel in Mental Disability Cases}

\author{
Michael L. Perlin*
}

This article questions the assumption that mentally disabled individuals are regularly afforded competent counsel. It finds that such counsel is frequently not available and that our failure to challenge this assumption threatens to make illusory reform efforts by lawyers and mental health professionals alike. The presence of vigorous, independent counsel is critical, especially since legal rights are not self-executing. Such counsel serves an educative function in the entire process, seeks to assure the implementation of collateral legal rights, and avoids the "underidentification" of mental disability cases. These functions have become more important as the political and social climate has changed and as the subject matter has become more complex. A series of reform recommendations is offered to litigators, policy makers, judges, and legislators.

One of the basic maxims of trial practice is the prohibition against assuming a fact not in evidence. Lawyers cannot ask a question on cross-examination that assumes such a fact ("Have you stopped beating your spouse?" is the most notorious example) nor can they assume such a fact either in framing a hypothetical or in a summation. A similar proscription bars judges from assuming such facts as predicates to their application of law in their opinions. There is nothing contro-

\footnotetext{
* The author wishes to acknowledge Debbie Dorfman for her research help, David Wexler, Ingo Keilitz, Bob Sadoff, and Joel Dvoskin for their helpful comments and encouragement, and Eric Janus, Bob Dinerstein, and Natalie Reatig for their helpful and patient explanations about (respectively) the Minnesota and Virginia commitment systems and the federal Protection and Advocacy Act. This article is adapted from remarks made at the Symposium on Mental Health and Justice Systems Interactions, sponsored by the National Center for State Courts, Arlington, VA, November 1990. Reprint requests should be addressed to Professor Perlin, New York Law School, 57 Worth St., New York, NY 10013.
} 
versial about these rules; they have always governed litigation practice and procedure. $^{1}$

Yet, much of the discourse of the past several years dealing with all aspects of mental disability law assumes a major fact nowhere in evidence: that mentally disabled individuals are regularly afforded competent counsel to represent them in the whole array of litigation, counseling, negotiating, and advocacy services in which counsel is expected to play an important role. ${ }^{2}$ The general acceptance of this illusion has seemingly lulled us into a corollary set of assumptions-about commitment law, institutional rights law, the impact of mental disability on the criminal trial process, and the legal rights of the formerly institutionalized-that has seriously, perhaps fatally, affected the way we view these underlying substantive and procedural legal issues.

The growth and development of mental disability law over the past two decades has been analyzed through many different filters. Variously, it is seen as (a) an outgrowth of the "civil rights revolution" (through which patients and expatients replicated the experiences of other disenfranchised and marginalized individuals) ${ }^{3}$; (b) a result of changes in funding mechanisms (in which the existence of financial incentives to reduce patient population-never complemented by parallel means of providing adequate program funding in community locations ${ }^{4}$-helped create a universe in which tightened substantive commitment standards and more elaborate procedural due process protections at commitment

'See e.g., D. Louisell \& C. Mueller, Federal Evidence 334, at 415-16 (1979); Myers, The Child Witness: Techniques for Direct Examination, Cross-Examination, and Impeachment, 18 Pac. L.J. 801,857 (1987) (basic maxim); Berger v. United States, 295 U.S. 78, 84 (1935); McIntyre v. State, 1990 WL 124141 (Ala. Cr. App. 1990), at 1 (bar on cross-examination); See e.g., Stockwell v. Stockwell, 116 Idaho 297, 301, 775 P. 2d 611, 615 (1989) (Johnson, J., concurring); State v. Apostle, 8 Conn. App. 216, 512 A. 2d 947, 956 (1986) (spouse-beating question); Thomas v. Myers, 655 S.W. 2d 695, 697 (Mo. Ct. App. 1983); Pippin v. St. Joe Minerals Corp., 799 S.W. 2d 898, 903 (Mo. Ct. App. 1990) (bar on use in hypothetical); Crosslin v. State, 489 So. 2d 680, 683-84 (Ala. Ct. App. 1986) (bar on use on summation). Justice Scalia's opinion in Arkansas Writers' Project, Inc. v. Ragland, 481 U.S. 221 (1987), is criticized for such assumptions in Sobel, First Amendment Standards For Government Subsidies of Artistic and Cultural Expression: A Reply to Justices Scalia and Rehnquist, 41 Vand. L. Rev. 517, 523 (1988).

${ }^{2}$ For the classic statement of this position, see Stone, The Myth of Advocacy, 30 Hosp. \& Commun. Psychiat. 819, 820-22 (1979); see also, Reinert, A Living Will for a Commitment Hearing, 31 Hosp. \& Commun. Psychiat. 857 (1980); compare Perlin, Psychiatric Hospitalization: Some Predictions for the 80's, in Critical Issues in American Psychiatry and the Law 239, 260-61 (R. Rosner ed. 1982), and Perlin, Mental Patient Advocacy by a Patient Advocate, 54 Psychiat. Q. 169, 173 (1982) (criticizing Stone). As I discuss below, this assumption is shared by key Congressional leaders, see infra note 91, and federal judges, see infra note 59. Paradoxically, overaggressive advocacy on the part of patients' lawyers has recently become the target of severe criticisms by psychiatrists, elected political officials, and others, who focus blame on such advocacy efforts as a primary cause of homelessness among deinstitutionalized patients. See generally, Perlin, Book Review of A. B. Johnson, Out of Bedlam: The Truth About Deinstitutionalization, 8 N.Y.L. Sch. J. Hum. Rts. 557 (1991); see also infra text accompanying notes 107-10.

${ }^{3}$ See Perlin, Rights of Ex-Patients in the Community: The Next Frontier? 8 Bull. Am. Acad. Psychiat. \& L. 33, 34 (1980).

${ }^{4}$ See E. F. Torrey, Nowhere to Go; The Tragic Odyssey of the Homeless Mentally Ill 25-29, $112-18$ (1988). 
stated-is that vigorous (perhaps overvigorous) counsel is readily available. ${ }^{10}$ This incorrect assumption has helped create a mirage that has effectively taken off the agenda what is perhaps the most important remaining substantive question of mental disability law: Do the institutionalized mentally disabled (or those formerly institutionalized or in danger of institutionalization) have access to adequate, structured counsel? ${ }^{11}$ Resolution of this question leads inexorably to the next level inquiry: If such counsel is not available, what impact does that have on the future of both mental disability law and the lives of the population in question?

While there has been some episodic evidence of bar development, while some jurisdictions have developed statewide or locality-wide specialized advocacy services, while the implementation of the Protection and Advocacy For the Mentally Ill Act (P\&A Act) has ensured the availability of some legal counsel in every state, and while the importance of counsel is-finally-being appreciated, ${ }^{12}$ the overall picture is little better than it was in 1978 when the initial recommendation of President Carter's Commission on Mental Health's Task Force on Legal and Ethical Issues was the passage of legislation "which would establish and adequately finance a system of comprehensive advocacy services for mentally handicapped persons." 13 And, because the assumption that some kind of counsel is now available has transformed the topic into a nonissue, it is more essential than ever that we confront the underlying reality: It is little more than an illusion that the legal system is responsive to the litigational and representational needs of mentally disabled individuals. Such individuals remain systematically underrepresented in all matters related to their disability. ${ }^{14}$

In Part I, I will restate the historical critique of the role of counsel in cases involving mentally disabled persons and will briefly sketch out the varying models of appointed counsel available in such cases. ${ }^{15}$ In Part II, I will develop my thesis that our failure to address this question threatens to render illusory all of the law reform efforts, social and political developments, and "rights talk" that have

the fulfillment of such obligations. For the few cases where states have challenged orders that allegedly obliged a hospital to confine a patient inappropriately, see Wexler, supra note 5, at 200.

${ }^{10}$ See e.g., E. F. Torrey, supra note 4, at 156-59; Lamb, Deinstitutionalization and the Homeless Mentally Ill, 35 Hosp. \& Commun. Psychiat. 899, 902 (1984) (criticizing patients' rights lawyers as a major force behind inappropriate deinstitutionalization and resulting homelessness). I consider this critique carefully in Perlin, Competency, Deinstitutionalization and Homelessness: A Story of Marginalization, 28 Hou. L. Rev. 63, 86-88 (1991).

${ }^{11}$ On the different models of "organized" and "regularized" counsel, see $2 \mathrm{M}$. Perlin, supra note 5 , $\$ \$ 8.06-8.10$.

${ }^{12}$ Early bar demonstration projects are discussed in $2 \mathrm{M}$. Perlin, supra note $5, \S 8.10$, at $78-82$, see also id. at $\$ 8.08$ (discussing New Jersey and New York programs in detail); id. at 8.16 (discussing 42 U.S.C. $\$ 10801$ et seq. (Pamphlet 1988) (P\&A Act)).

${ }^{13}$ Mental Health and Human Rights: Report on the Task Panel on Legal and Ethical Issues, 20 Ariz. L. Rev. 49, 54 (1978) (Task Panel Report).

${ }^{14}$ See Herr, supra note 6, at 377. Although the Supreme Court has never found that there is a constitutional right to counsel in involuntary civil commitment cases, other case law is virtually unanimous in such a finding. See $2 \mathrm{M}$. Perlin, supra note 5 , Comment to $\$ 8.06$, at 755 .

${ }^{15}$ See infra text accompanying notes $19-37$. 
emerged as standard discourse in this area over the past two decades, ${ }^{16}$ and will explain why this is so important, focusing particularly on the dilemma that this creates in a system such as ours in which rights are not self-executing and on the consequential "real world" implications of such a system. ${ }^{17}$ In Part III, I will conclude and offer some modest suggestions for reform. ${ }^{18}$

\section{PROVISION OF COUNSEL TO THE MENTALLY DISABLED}

The record of the legal profession in providing meaningful advocacy services to mentally disabled persons has been grossly inadequate. ${ }^{19}$ Before the early 1970 s, court hearings were infrequently required prior to the ordering of involuntary civil commitment, ${ }^{20}$ counsel was rarely provided, and courts regularly defaulted in their decision-making responsibilities. ${ }^{21}$ The historical critique was unanimous:

Traditional, sporadically-appointed counsel . . . were unwilling to pursue necessary investigations, lacked . . . expertise in dealing with mental health problems, and suffered from "rolelessness," stemming from near total capitulation to experts, hazily defined concepts of success/failure, inability to generate professional or personal interest in the patient's dilemma, and lack of a clear definition of the proper advocacy function. As a result, counsel ... functioned "as no more than a clerk, ratifying the events that transpired, rather than influencing them." 22

Commitment hearings were little more than a ritual, adding only a "falsely reassuring patina of respectability to the proceedings." ${ }^{23}$ In one case study, counsel was so inadequate that a patient's chance for release was actually greater if there was no lawyer present. ${ }^{24}$ On the other hand, when active counsel was involved, such lawyers played a critical role in involuntary civil commitment proceedings. ${ }^{25}$ Studies of jurisdictions where such lawyers were available re-

${ }^{16}$ See infra text accompanying notes $38-48$.

${ }^{17}$ See infra text accompanying notes $49-117$.

${ }_{18}^{18}$ See infra text accompanying notes 118-21.

${ }^{19}$ Much of the text that accompanies notes 20-37, infra, is adapted from 2 M. Perlin, supra note 5, Chapter 8. On the question of inadequacy of counsel, see generally, Perlin \& Sadoff, Ethical Issues in the Representation of Individuals in the Commitment Process, 45 Law \& Contemp. Probs. 161 (Summer 1982).

20 This section will deal mainly with the availability of counsel as the involuntary civil commitment hearings. On the question of the right to counsel in matters beyond commitment and release, see 2 M. Perlin, supra note $5, \S 8.35$.

${ }^{21}$ See Hiday, The Attorney's Role in Involuntary Civil Commitment, 60 N.C. L. Rev. 1027, 1030 (1982).

${ }^{22}$ Perlin \& Sadoff, supra note 19, at 164 (footnotes omitted).

${ }^{23}$ Hiday, supra note 21, at 1030, quoting Andalman \& Chambers, Effective Counsel for Persons Facing Civil Commitment: A Survey, a Polemic, and a Proposal, 45 Miss. L.J. 43, 72 (1974).

${ }^{24}$ Andalman \& Chambers, supra note 23 , at 72.

${ }^{25}$ For early surveys, see e.g., Kumasaka \& Stokes, Involuntary Hospitalization: Opinions and Attitudes of Psychiatrists and Lawyers, 13 Compreh. Psychiat. 201 (1972); Silverberg, The Civil Com- 
flected the significance of "regularized, organized systems[s] of legal service delivery .... staffed with full-time advocates whose sole job it is to provide legal representation to the handicapped."26

While there is now some sort of provision in each jurisdiction for the provision of counsel to individuals facing commitment, ${ }^{27}$ these systems vary widely in their comprehensiveness, in the depth of their mandate, in their commitment to specialization, and in their levels of payment. ${ }^{28}$ As a result, the quality of the representation is uneven, varying both from state to state and within states. ${ }^{29}$ While scholars and critics are virtually unanimous that advocacy services to the mentally disabled should be provided through organized regular mechanisms ${ }^{30}$ (such as the New York Mental Hygiene Legal Service, the New Jersey Division of Mental Health Advocacy, or the Ohio Legal Rights Advisors), ${ }^{31}$ the vast majority of lawyers who represent the disabled on individual matters are appointed on individual bases. ${ }^{32}$ Such appointments almost never measure up to the appropriate ethical or constitutional standards for such representation ${ }^{33}$; while there is

mitment Process: Basic Considerations, in 1 Legal Rights of the Mentally Handicapped 103, 109 (B. J. Ennis \& P. Friedman, eds. 1973).

${ }^{26}$ Perlin \& Sadoff, supra note 19, at 173 .

${ }^{27}$ See Elkins, Legal Representation of the Mentally Ill, 82 W. Va. L. Rev. 157, 158 (1979). A taxonomy for these provisions is suggested in $2 \mathrm{M}$. Perlin, supra note 5, \$8.06, at 756-58.

${ }^{28}$ The different programs are described in id., 8.07.

${ }^{29}$ See id., \$\$8.17-19; Zander, supra note 5 (discussing county-by-county variance in Wisconsin).

${ }^{30}$ Andalman \& Chambers, supra note 23, at 75-79; Durham \& LaFond, The Empirical Consequences and Policy implications of Broadening the Statutory Criteria for Civil Commitment, 3 Yale Law \& Pol'y Rev. 395, 425-28, 439-43 (1985); see also, Task Panel Report, supra note 13, at 56:

An essential feature of . . . advocacy systems should be their effort to provide a continuity of legal services to [mentally disabled] persons at all stages of their contact with the mental disability system. ... In addition to attorneys (an "indispensable element in seeking and securing many types of remedies"'), the advocacy system should be staffed by persons trained as "mental health professionals"..., lay advocates, present and former recipients of mental health services, so as to provide a full-time staff with the necessary academic training and practical experience to provide full advocacy serviced for its clientele.

(footnotes omitted).

${ }^{31}$ See N.Y. Ment. Hyg. L. $\$ 47.03$ (McKinney 1986); N.J. Stat. Ann. §52:27E-23 et seq. (West Supp. 1985); Ohio Stat. Ann. $\$ 51.23 .60$ (1990). The New York system is discussed in Gupta, New York's Mental Health Information Service: An Experiment in Due Process, 25 Rutgers L. Rev. 405, 448 (1971); the New Jersey system in Heffner, Legislative Oversight: An Analysis of L. 1974, Chapter 25, Department of the Public Advocate Act, 1 Seton Hall Legis. J. 75, 80-81 (Summer 1976).

32 M. Perlin, supra note 5, \$8.11, at 783-84.

${ }^{33}$ For an early study, see Cohen, The Function of the Attorney and the Commitment of the Mentally Ill, 44 Tex. L. Rev. 424 (1966). On the broader question of the duties of lawyers representing putatively incompetent clients, see Margulies, "Who Are You To Tell Me That?" Attorney-Client Deliberation Regarding Nonlegal Issues and the Interests of Nonclients, 68 N.C. L. Rev. 213, 225 n. 83 (1990); Tremblay, On Persuasion and Paternalism: Legal Decisionmaking and the Questionably Competent Client, 1987 Utah L. Rev. 515, 517-21. To a significant extent, this inadequate job may reflect the less-than-vigorous quality of representation implicitly or explicitly favored by a significant number of trial judges assigned to such cases. Experienced lawyers confirm that attempts at vigorous cross-examination and at the development of novel defenses are frequently rebuffedangrily - by trial judges assigned to civil commitment dockets. (Personal communication, Professor 
some reported recent improvement in this area, full-time, structured counsel is inevitably more effective. ${ }^{34}$ Also, while prestigious commissions and expert commentators have called on the private bar to commit greater resources and efforts to this area (both by providing representation and training), little has yet been done ${ }^{35}$ Notwithstanding the major contributions of a handful of lawyers in private practice who have devoted their careers almost exclusively to the representation of the handicapped, ${ }^{36}$ there is little reason to be optimistic about the likelihood of universal invigorated private representation of this population in the near future.

\section{THE ILLUSION OF LEGAL RIGHTS AND THE SIGNIFICANCE OF COUNSEL}

\section{A. The Rights Illusion}

As long as mentally disabled individuals are not assured of access to adequate, "regularized," and well-structured counsel, many of the questions to which scholars, clinicians, litigators, and courts devote their time and energy will have little ultimate impact, and all of the "rights talk" and law reform efforts of the past two decades will be little more than an illusion. ${ }^{37}$ Consider variously these issues:

- In interpreting substantive civil commitment criteria, establishing the exact definition of an "overt act" or the "imminence" of danger as a prelude to involuntary civil commitment. ${ }^{38}$

Keri Gould, April 26, 1991) (Professor Gould was previously senior attorney for the Mental Hygiene Legal Service, New York City.) My own experience-three years as a deputy public defender specializing in trials of mentally disabled defendants and eight years as director of New Jersey's Division of Mental Health Advocacy-is identical.

${ }^{34}$ Hiday, Representing Respondents Under New Civil Commitment Statutes: An Analysis of Counsel's Role In and Out of the Courtroom, 5 Law \& Pol'y Q. 438, 452 (1983). This conclusion depends on another assumption: that the trial judge is even aware that organized counsel is available to represent the individual facing commitment. See In re Commitment of C.P.K., 516 So. 2d 1323, 1325 (La. Ct. App. 1987) (trial court apparently unaware of existence of state-funded Mental Health Advocacy Service).

${ }^{35}$ Compare e.g., Task Panel Report, supra note 13, at 59, to see $2 \mathrm{M}$. Perlin, supra note $5, \$ 8.11$, at $786 \mathrm{n} .216$ (critiquing earlier private bar efforts).

${ }^{36}$ Such lawyers have frequently played important lead roles in many of the most important mental disability law reform cases litigated over the past two decades, and, in a few instances, have devoted their private practice nearly exclusively to such work. See e.g., S. S. Herr, The New Clients: Legal Services for Mentally Retarded Persons 64 n. 239 (1979); Schwartz, Fleischner, Schmidt, Gates, Costanzo, \& Winkelman, Protecting the Rights and Enhancing the Dignity of People With Mental Disabilities: Standards for Effective Legal Advocacy, 14 Rutgers L.J. 541, 550-53 (1983); Herr, supra note 6 , at 356.

${ }^{37}$ See generally, Lottman, Paper Victories, in Paper Victories and Hard Realities: The Implementation of the Legal and Constitutional Rights of the Mentally Disabled 93 (V. Bradley \& G. Clarke eds. 1976).

${ }^{38}$ Compare e.g., Lessard v. Schmidt, 349 F. Supp. 1078, 1093 (E. D. Wis. 1972) (commitment must be premised on a recent "overt act"), to United States ex rel. Mathew v. Nelson, 461 F. Supp. 707, 
- In applying the Fourteenth Amendment to the procedures employed in such commitment determinations, deciding whether time limits in commitment certificate applications must be interpreted narrowly or expansively. ${ }^{39}$

- In determining the extent of the state's obligation to provide a "right to training, ${ }^{, 40}$ whether individual clinical and treatment issues are cognizable at involuntary civil commitment hearings after Youngberg $v$. Romeo. ${ }^{41}$

- In establishing the procedures that must accompany the right to refuse treatment, considering whether a "judicial officer model" or an "independent evaluator/administrative model" is the most appropriate means of vindicating the right. ${ }^{42}$

- In weighing the interplay between deinstitutionalization and homelessness, assessing whether a patient's refusal to take medication is a sufficient predicate upon which to preclude the consideration of outpatient or community treatment. ${ }^{43}$

- In considering the implication of mental disability for the trial of criminal cases, such issues as the length of time that an indictment can be kept open against a defendant found incompetent to stand trial in accordance with Jackson $v$. Indiana, ${ }^{44}$ the appropriateness of retaining the "volitional" prong of the insanity defense in a post-Hinckley universe,${ }^{45}$ the applicability of Ake v. Oklahoma ${ }^{46}$ in non-insanity defense cases, ${ }^{47}$ or the assessment of competency in determining whether a death row prisoner may be executed. ${ }^{48}$

712 (N.D. Ill. 1978) (rejecting the "overt act" requirement), and see id. at 711 (defining "overt act"); see generally, $1 \mathrm{M}$. Perlin, supra note 5, \$2.13. On the question of "imminence" of harm, see In re Harris, 98 Wash. 2d 276, 654 P. 2d 109, 112-13 (1982) (collecting cases).

${ }^{39}$ Compare e.g., State ex rel. Hashimi v. Kalil, 388 Mass. 607, 446 N.E. 2d 1387 (1983) (strict interpretation), to Matter of Z.O., 197 N.J. Super. 330, 484 A. 2d 1287 (App. Div. 1984) (broad interpretation).

${ }^{40}$ See Youngberg v. Romeo, 407 U.S. 307 (1982).

${ }^{41}$ Compare Matter of Commitment of J.L.J., 210 N.J. Super. 1, 509 A. 2d 184, 186 (App. Div. 1985) (issue cognizable), to In re Harhut, 367 N.W. 2d 628, 632 (Minn. Ct. App. 1985) (issue generally not cognizable).

${ }^{42}$ Compare Rivers v. Katz, 67 N.Y. 2d 485, 495 N.E. 2d 337, 504 N.Y.S. 2 d 74 (1986) (judicial model), to Rennie v. Klein, Civil Action No. 77-2624 (D. N.J., Aug. 16, 1984) (consent order), reprinted in 2 M. Perlin, supra note $5, \$ 5.37$ (administrative model).

${ }^{43}$ See In re J.B., 217 Mont. 504, 705 P. 2d 598, 602 (1985); on this question generally, see Perlin, supra note 10 , at 123 .

44406 U.S. 715 (1972).

45 See generally, Perlin, Unpacking the Myths: The Symbolism Mythology of Insanity Defense Jurisprudence, 40 Case West. Res. L. Rev. 599 (1989-90).

46470 U.S. 68 (1985). See infra text accompanying notes 78-82.

${ }^{47}$ See e.g., Interest of Goodwin, 366 N.W. 2d 809, 814-15 (N.D. 1985) (civil commitment case); In re Brown, 1986 WL 13385 (Ohio Ct. App. 1986), at 5 (child custody); Matter of Sanders, 108 N.M. 434, 439, 773 P. 2d 1241, 1246 (Ct. App. 1989) (treatment guardianship revocation).

48 See e.g., Heilbrun, Treatment of Competency for Execution: An Overview, 5 Behav. Sci. \& L. 383 (1987). 
If adequate counsel is not available to represent the mentally disabled individuals in respect to these issues, then the legal disposition of these difficult cases will have little ultimate impact on the way that the mental disability and justice systems interact. Quality counsel provides the most likely way-perhaps the only likely way-to ensure the effectuation of dignity values in all of these cases. Without implementation and vindication of this right, the entire enterprise of "mental disability law" is in danger of remaining little more than an intellectually interesting but substantively meaningless parlor game. "Progress"- as measured by case law development and statutory reform-will be, at best, self-limiting, and, at worst, regressive.

\section{B. Significance of Counsel}

In order for players in the mental disability/justice system to effectuate any meaningful change on behalf of mentally disabled persons, it is necessary to focus on the critical role of counsel for a series of overlapping and interrelated reasons.

\section{Rights Are Not Self-Executing}

Legal rights are not necessarily self-executing. ${ }^{49}$ The declaration by a court of a right "to" a service or a right to be free "from" an intrusion does not in se provide that service or guarantee freedom from intrusion. A right is only a paper declaration without an accompanying remedy, ${ }^{50}$ and, without counsel (so as to best guarantee enforcement), there is little chance that the rights "victories" that have been won in test case and law reform litigation in this area will have any impact on the mentally disabled population. ${ }^{51}$

Three examples should suffice. In 1972, the Supreme Court decided in Jackson $v$. Indian ${ }^{52}$ that it violates due process to commit an individual awaiting criminal trial for more than the "reasonable period of time" needed to determine

${ }^{49}$ Winick, Restructuring Competency to Stand Trial, 32 U.C.L.A. L. Rev. 921,941 (1985). See also, e.g., Harvey v. State, 774 P. 2d 87, 98 (Wyo. 1989) (quoting The Douglas Letters: Selections From the Private Papers of Justice William O. Douglas 162 (M. Urofsky ed. 1987) (bill of rights freedoms)); Note, A Public Goods Approach to Calculating Reasonable Fees Under Attorney Fee Shifting Statutes, 189 Duke L.J. 438, 465 n. 151, quoting S. Rep. No. 1011, 94th Cong., 2d Sess., at 6, reprinted in 1976 U.S. Code Cong. \& Admin. News S908 (civil rights laws not self-executing); People v. Kern, 75 N.Y. 2d 638, 651, 555 N.Y.S. 2d 647, 653, 554 N.E. 2d 1235, 1241 (1990) (same); State v. Duman, 1990 WL 83986 (Ohio Ct. App. 1990), at 2 (speedy trial rights).

${ }^{50}$ See generally, Zeigler, Rights Require Remedies: A New Approach to the Enforcement of Rights in the Federal Courts, 38 Hastings L.J. 665 (1987).

${ }^{51}$ According to Professor Zeigler:

[A] right without a remedy is not a legal right; it is merely a hope or a wish. . . . Unless a duty can be enforced, it is not really a duty; it is only a voluntary obligation that a person can fulfill or not at his whim. . .

... Rights promote well-being in the broadest sense. They secure the dignity and the integrity of human beings. ... Rights give people control over their lives and are essential to self-respect.

Id. at 678-79 (footnotes ommitted).

52406 U.S. 715 (1972). 
"whether there is a substantial chance of his attaining the capacity to stand trial in the foreseeable future." 53 Yet, 13 years later, Professor Bruce Winick reported that, in almost half of the states, Jackson had yet to be implemented, and the pre-Jackson problems (of overlong commitments) "still persist[ed]." 54 In another setting, even though the District of Columbia Code contains a provision that patients can invoke seeking either periodic review of their commitment or an independent psychiatric evaluation, evidence developed in a recent case has revealed that, in the 22 years since the passage of the law in question, not a single patient had exercised his rights to this statutory review. ${ }^{55}$ Similarly, hard-fought institutional reform "victories" in cases declaring broad rights to treatment had little "real world" impact when it became clear that there were no lawyers available to ensure that the decisions would be properly implemented. ${ }^{56}$ Because rights are not self-executing, the need for counsel is thus further magnified.

The early flush of victories in test cases filed on behalf of mentally disabled individuals-both in procedural and substantive challenges to commitment and release laws and in wholesale attacks on conditions of institutional confinementmay have lulled observers into thinking, incorrectly, that the main battlefield of mental disability litigation was the summary judgment motion in the federal dis-

${ }^{53} I d$. at 733 .

${ }^{54}$ Winick, supra note 49, at 940; see also, R. Roesch \& S. Golding, Competency to Stand Trial 121-26 (1980); Weiner, Mental Disability and the Criminal Law, in S. J. Brakel, J. Parry \& B. Weiner, The Mentally Disabled and the Law 693, 704 (3d ed. 1985).

${ }^{55}$ Streicher v. Prescott, 663 F. Supp. 335, 343 (D.D.C. 1987); see generally, Perlin, Morality and Pretextuality, Psychiatry and Law: Of "Ordinary Common Sense," Heuristic Reasoning, and Cognitive Dissonance, 19 Bull. Am. Acad. Psychiat. \& L. 131, 133 (1991). See also, Wexler, The Waivability of Recommitment Hearings, 20 Ariz. L. Rev. 175, 176-78 (1978) (discussing problems inherent in patient-initiated review mechanisms).

${ }^{56}$ On the question of compliance with the court's broad staffing orders in the landmark right to treatment case of Wyatt v. Stickney, 344 F. Supp. 373 (M.D. Ala.), 344 F. Supp. 387 (M.D. Ala. 1972), aff d sub. nom. Wyatt v. Aderholt, 503 F. 2d 1305 (5th Cir. 1974), see generally, Wyatt V. Stickney: Retrospect and Prospect (L. R. Jones \& R. Parlour, eds. 1981); see also, O'Reilly \& Sales, Setting Physical Standards for Mental Hospitals: To Whom Should the Courts Listen? 8 Int'1 J.L. \& Psychiat. 301 (1986); O'Reilly \& Sales, Privacy for the Institutionalized Mentally Ill: Are Court-Ordered Standards Effective? 11 Law \& Hum. Behav. 41 (1987). There are many other related potential examples involving potential collateral actions. Although several cases have vindicated patients' right to vote, see e.g., Boyd v. Board of Registrars of Voters of Belchertown, 368 Mass. 631, 334 N.E. 2d 629 (1975); Carroll v. Cobb, 139 N.J. Super. 439, 354 A. 2d 355 (App. Div. 176), this right becomes an empty shell if, for instance, there is no staff worker available to drive the patient to a poll. The presence of counsel could ensure vindication of this right, by filing a supplemental action to order the hospital to provide such transportation, compare Reiser v. Prunty, 727 P. 2d 538, 547 (Mont. 1986) (hospital and psychiatrist had no responsibility to protect constitutional right to vote of patient detained under emergency detention statute). Similarly, a court order mandating the constitutional right to visitation, see e.g., Schmidt v. Schubert, 422 F. Supp. 57, 58 (E.D. Wis. 1976), becomes meaningless if a hospital announces that it cannot provide adequate staff to implement such visitation rights. Again, counsel would be needed to ensure that the original plaintiff have an enforceable remedy. (Personal communication, Dr. Robert L. Sadoff, Feb. 2, 1991.) 
trict court. ${ }^{57}$ Without the constant presence of counsel, victories in cases such as these remain in danger of deteriorating into "paper victories." 58

\section{The Myth of Adequate Counsel}

Also, it has been supposed for over a decade that counsel is regularly available to mentally disabled persons in individual matters involving their commitment to, retention in, and release from psychiatric hospitals. ${ }^{59}$ As previously discussed, ${ }^{60}$ this availability is largely illusory. Further, such representation is rarely available in a systemic way in law reform or test cases and is rarely provided in any systemic way in cases that involve counseling or negotiating short of actual litigation. ${ }^{61}$

Empirical surveys are consistent. The quality of counsel remains the single most important factor in the disposition of cases in involuntary civil commitment systems and in the trial of mentally disabled criminal defendants. ${ }^{62}$ It is only when counsel is provided in an organized, specialized, and regularized way that there is

${ }^{57}$ This thesis is discussed carefully and comprehensively in its historical perspective in Wexler, Putting Mental Health Into Mental Health Law: Therapeutic Jurisprudence, this issue, 16 Law \& Hum. Behav. 27-38 (1991).

${ }^{58}$ See, for the classic inquiry, Lottman, supra note 37.

${ }^{59}$ See e.g., Stone, supra note 2, at 821-22 (charging that a "one-sided advocacy system" exists in which patients are regularly represented by zealous and conscientious lawyers); see also, e.g., French v. Blackburn, 428 F. Supp. 1351, 1357 (M.D.N.C. 1977), aff $d$ o.b. 443 U.S. 901 (1979) (rejecting plaintiff's assumption that lawyer in involuntary civil commitment case will not act in client's best interest). It should be self-evident that we cannot assume adequacy of counsel from the mere fact that a "warm body" stands next to the person in court who faces involuntary commitment. This discussion may appear to assume another fact that it perhaps not in evidence: That patients actually receive adequate treatment at such hospitals so as to lessen or ameliorate their mental illness. For an analysis of our assumption of treatment staff competency in this regard, and 60 its implications for deinstitutionalization policies, see Perlin, supra note 9, at 124-25.

${ }^{60}$ See supra text accompanying notes 19-28.

${ }^{61}$ See e.g., Vitek v. Jones, 445 U.S. 480, 500 (1980) (Powell, J., concurring) (counsel not required in hearing held to determine whether prison inmate should be transferred to state psychiatric hospital); Washington v. Harper, 110 S. Ct. 1028, 1044 (1990) (counsel not required in hearing held to determine whether prisoner has right to refuse involuntary imposition of psychotropic medication). Statistics compiled by the National Institute of Mental Health regarding the provision of counsel by P\&A systems to institutionalized individuals suggest that class-action-type cases were instituted in fewer than half of all jurisdictions in fiscal year 1989. Although the same statistics show that 91 class actions were "initiated" during that time period, 46 of these are attributed to only two states. This statistical anomaly is perhaps best explained by variance in means of data collection; in those jurisdictions, the "initiation" of a class action apparently referred to the provision of any sort of counseling or advocacy service to more than one client on any question of legal rights. National Institute of Mental Health, FY 1989 Report on Activities Under PL 99-319, the Protection and Advocacy For Mentally Ill Individuals Act 61, Table 9 (1990) (P\&A Report).

${ }^{62}$ See $2 \mathrm{M}$. Perlin, supra note $5, \$ 8.02$, at 744 . Beyond the scope of this paper is the important question of the implications of lawyers' imposition of their own political or social goals and ideologies on their clients. For an important perspective on this question in this context, see Herr, supra note 6 , at 357. 
more than a random chance of lasting, systemic change. Yet, few states appear willing to provide such counsel in such a manner. ${ }^{63}$

A contrast between the development of case law in Virginia and Minnesota is especially instructive. Notwithstanding the fact that Virginia is approximately $15 \%$ more populated than Minnesota, ${ }^{64}$ in the decade from 1976 to 1986, there were only two published litigated civil cases in Virginia involving questions of mental hospitalization, while in Minnesota during the same period of time, there were at least 101 such cases. ${ }^{65}$ Virginia has no tradition of providing vigorous counsel to the mentally disabled, ${ }^{66}$ whereas Minnesota does make such provision. ${ }^{67}$

${ }^{63}$ See generally, id. $\$ 8.08$. Beyond the scope of this paper is a detailed investigation of the specific ethical issues that must be considered in this context. For discussions of this question, see e.g., Perlin \& Sadoff, supra note 19;2 M. Perlin, supra note 5, \$\$8.20-8.23. Also beyond the scope of this article is a consideration of other economically based issues. Most persons facing involuntary civil commitment are indigent, and any assessment of counsel must weigh this factor as well. See e.g., Perlin, An Invitation to the Dance: An Empirical Response to Chief Justice Warren Burger's "Time-Consuming Procedural Minuets" Theory in Parham v. J.R., 9 Bull. Am. Acad. Psychiatry \& L. 149, 157, 163 n. 72 (1981) (210 of 213 juveniles facing civil commitment in sample studied were indigent). On the special issues affecting lawyers in the representation of the poor in general, see Alfieri, The Antinomies of Poverty Law and a Theory of Dialogic Empowerment, 16 N.Y.U. Rev. L. \& Soc'l Change 659 (1987-88).

${ }^{64}$ According to the 1988 census, Virginia's population was $6,015,000$, while Minnesota's was $4,307,000$.

${ }^{65}$ Keilitz, Casey, \& Keilitz, A Study of the Emergency Mental Health Services and Involuntary Civil Commitment Practices in Virginia 47 (1989). Though Minnesota court rules command patients' counsel to "advocate vigorously" on behalf of their clients, see Minn. R. Commitment, Rule 1.01 (1990), there is no comparable provision in Virginia law; $c f$. Va. Stat. \$19.2-169.5 (1990) (role of counsel in raising insanity in criminal proceedings).

${ }^{66}$ See Keilitz, Casey \& Keilitz, supra note 65 , at 39-45, and especially at 42 ("Given the absence of a district attorney representing the Commonwealth, or an attorney representing the petitioner, commitment proceedings are at best, quasi-adversarial"). For an analysis of locality-by-locality involuntary civil commitment practice in Virginia, see Bodman, The Nether World of Involuntary Commitment, Wash. Post (Jan. 8, 1984). At the time that Boden wrote, lawyers in Virginia were paid $\$ 25$ for preliminary hearings and another $\$ 25$ for a final hearing.

${ }^{67}$ Under Minn. R. Commitment, Comment to Rule 1 (1990):

A. All proceedings under the [Act] are adversarial. Minimum adversary representation ordinarily includes, but is not limited to:

1. being familiar with statute and case law and court rules which govern commitment proceedings; and

2. interviewing respondent no later than 24 hours after confinement ... . ; and

3. reviewing respondent's medical records ... early enough to insure sufficient time to investigate and secure additional medical evaluations, and/or prepare for the hearings; and

4. contacting or interviewing all persons whose testimony might tend to support respondent's position and subpoenaing witnesses if necessary; and,

5. investigating alternatives less restrictive than those sought in the petition; and

6. attempting to interview prior to the hearing any persons who might testify for the petitioner at the hearing; and

7. informing respondent of the latter's rights, including the right to appeal.

B. [This rule] is intended to insure that once appointed, the same lawyer will continue to represent respondent. ... . 
The existence of this sort of disparity is especially disturbing in light of the detailed empirical database that has been developed by staff members of the National Center for State Courts and their colleagues, studying the provision of counsel in selected jurisdictions, ${ }^{68}$ as well as the comprehensive and thoughtful Commitment Guidelines. ${ }^{69}$ These reports and Guidelines-well documented in law reviews and in behavioral journals-could serve as a blueprint for national models of counsel provision. ${ }^{70}$ Yet, only one of the citations to these recommendations mentions the counsel provisions; ${ }^{71}$ similarly, the extent to which these

According to Professor Eric Janus, this court rule grew out of a study commissioned by the Minnesota Supreme Court on the involuntary civil commitment process and followed settlement of a suit that had sought to force Hennepin County to provide an independent panel of trained counsel to represent individuals at such hearings. Janus, now a professor at William Mitchell Law School, was formerly a litigator with the Minneapolis Legal Aid office that provided representation to mentally disabled persons. (Personal Communications, Professor Eric Janus, February 1, 1991 \& March 13 1991.)

${ }^{68}$ See e.g., Fitch, Involuntary Commitment of the Mentally Disabled: Implementation of the Law in Winston-Salem, North Carolina, 14 N.C. Cent. L.J. 406 (1984); Keilitz, Conn \& Giampetro, Least Restrictive Treatment of Involuntary Patients: Translating Concepts Into Practice, 29 ST. L.U.L.J. 691 (1985); Keilitz, Fitch \& McGraw, A Study of Involuntary Civil Commitment in Los Angeles County, 14 Sw. U.L. Rev. 238 (1984); Keilitz \& McGraw, The Least Restrictive Alternative Doctrine in Los Angeles County Civil Commitment, 6 Whittier L. Rev. 35 (1984); Keilitz \& Roach, A Study of Defense Counsel and the Involuntary Civil Commitment System in Columbus, Ohio, 13 Cap. U.L. Rev. 175 (1983); McGraw, Fitch, Buckley \& Marvell, Civil Commitment in New York City: An Analysis of Practice, 5 Pace L. Rev. 259 (1985); Van Duizend \& Zimmerman, The Involuntary Civil Commitment Process in Chicago: Practices and Procedures, 33 DePaul L. Rev. 225 (1984).

${ }^{69}$ See National Center For State Courts, Guidelines for Involuntary Civil Commitment (1986) (Guidelines). These Guidelines are considered carefully in Keilitz, NCSC Guidelines for Involuntary Civil Commitment: A Workable Framework for Justice in Practice, 39 Hosp. \& Commun. Psychiat. 398 (1988); Wexler, Reforming the Law in Action Through Empirically Grounded Civil Commitment Guidelines, 39 Hosp. \& Commun. Psychiat. 402 (1988); Appelbaum \& Roth, Assessing the NCSC Guidelines for Involuntary Civil Commitment From the Clinician's Point of View, 39 Hosp. \& Commun. Psychiat. 406 (1988).

${ }^{70}$ See e.g., Guidelines, supra note 69 , at $44-47$ (ensuring effective advocacy for patients' roles and duties of patients' counsel), and id. at 50-56 (means of appointing patients' counsel; prehearing duties of patients' counsel); see also, L. Arthur, S. Haimowitz \& R. Lockwood, Involuntary Civil Commitment: A Manual for Lawyers and Judges 9-14 (1988) (role of counsel; means of compensation), discussing Guidelines, supra note 69.

71 See Matter of Stokes, 546 A. 2d 356, 361 (D.C. Ct. App. 1988) (patient's counsel can play an important role in determining disposition alternatives), citing Guidelines, supra note 69.

For other references to the Guidelines, see In re Melton, 565 A. 2d 635, 646 (D.C. Ct. App. 1989), vacated 1990 WL 175025 (D.C. Ct. App., Nov. 7, 1990) (need for fact testimony at civil commitment hearing); K.C. v. State, 771 P. 2d 774, 777 (Wyo. 1989) (scope of appeal from civil commitment order); Stokes, 546 A. 2d at $361 \mathrm{nn} .6,10$ (least restrictive alternative requirement); Riese v. St. Mary's Hospital and Medical Center, 209 Cal. App. 3d 1303, 271 Cal. Rptr. 199, 209 (1987), appeal dismissed as improvidently granted, 259 Cal. Rptr. 669, 774 P. $2 \mathrm{~d} 698$ (1989) (refusal of medication). 
recommendations have had a significant impact on subsequent statutory developments is not clear. ${ }^{72}$

\section{Counsel's Educative Function}

The presence of structured counsel-of lawyers supported by mental health professionals - also serves an important internal educative function by making it more likely that all participants in the mental disability trial process-including judges - are sensitized to the social, cultural, and political issues that are involved in providing representation to such a marginalized class. ${ }^{73}$ The disappointing results reported over a decade ago by Dr. Normal Poythress (that merely training lawyers about psychiatric techniques and psychological nomenclature made little difference in ultimate case outcome ${ }^{74}$ ) tell us that education about the law and about the clinical details of mental illness are not enough; counsel must be attitudinally and ethically ${ }^{75}$ educated if they are to provide truly adequate representational services.

The perfunctory performance of counsel in the areas discussed in this article (where mental disability issues are central) contrasts sharply with lawyers' traditional zealousness in the representation of similarly disabled clients in civil law areas such as testamentary capacity, traumatic injury, or competency to make business decisions, where mental health issues are collateral. ${ }^{76}$ The converse is also true: Even though mental disability professionals rarely complain about exhaustive or intensive cross-examination in the latter group of cases, "they are often indignant when challenged by an attorney representing a patient in the commitment process." 77

72 Though there is some anecdotal evidence suggesting that the Guidelines served as a blueprint for statutory reform, there is no formal supporting written attribution (personal communication, Dr. Ingo Keilitz, February 6, 1991).

${ }^{73}$ See generally, Perlin \& Sadoff, supra note 19, at 168-73; 2 M. Perlin, supra note 5, §\$8.21-8.22.

${ }^{74}$ Poythress concluded that the "trained" lawyers' court behavior did not differ materially from that of "untrained" lawyers because the trained lawyers' attitudes toward their clients did not change, and such lawyers were not deterred from taking the "traditional, passive, paternal stance" towards their clients. Poythress, Psychiatric Expertise in Civil Commitment: Training Attorneys to Cope With Expert Testimony, 2 Law \& Hum. Behav. 1, 15 (1978). A representative trainee told Poythress: "I really enjoyed your workshop, and I've been reading over your materials and its [sic] all very interesting, but this is the real world, and we've got to do something with these people. They're sick." Id.

75 See D. Wexler, Mental Health Law 111 n. 55 (1981); see generally, Note. The Role of Counsel in the Civil Commitment Process: A Theoretical Framework, 84 Yale L.J. 1540 (1975). On the additional lawyering roles that counsel for the mentally disabled person must fill, see $2 \mathrm{M}$. L. Perlin, supra note 5, \$8.21, at 807-17.

${ }^{76}$ See 2 M. Perlin, supra 5, $\$ 8.20$, at 805 .

${ }^{77}$ Perlin \& Sadoff, supra note 19, at 165. At least one prominent forensic psychiatrist attributed such reluctance to exposure in an arena where the witness does not retain final authority as "professional narcissism." McGarry, Demonstration and Research in Competency for trial and Mental Illness, 49 B.U. L. Rev. 46 (1969).

Similarly, it has been observed that, while the states can generally provide "a very thorough examination" of a criminal defendant raising insanity as a plea to a murder indictment, such thoroughness is frequently sorely lacking in psychiatric status examinations that precede civil 


\section{Implementation of Collateral Rights}

Further, if counsel is not adequate, then it is unlikely that counsel will seek vigorous execution or implementation of other collateral rights. In Ake v. Oklahoma, for instance, the U.S. Supreme Court ruled that if a criminal defendant made a threshold ex parte showing that his sanity at the time of the offense was likely to be a "significant factor". at trial, he was constitutionally entitled to state-provided psychiatric assistance on this issue. ${ }^{78}$ In the subsequent 6 years, Ake has been read narrowly and with little creativity ${ }^{79}$; as a result, the rationale of Justice Marshall's opinion-that psychiatrists will be able to assist lay jurors "to make a sensible and educated determination" about the defendant's medical condition at the time of the offense" ${ }^{80}$-has rarely been complied with. If mentally disabled litigants ${ }^{81}$ were afforded more adequate counsel, it is likely that $A k e$ would have been implemented in a manner more in accordance with the spirit of the Supreme Court's decision. ${ }^{82}$

\section{Underidentification of Mental Disability Cases}

The problems in question are even further magnified where cases are not specifically identified as "mental disability cases" (e.g., a criminal trial where a mental status defense falls short of the invocation of the insanity plea; a child custody battle where parents' mental illness-but not their incompetency-is at issue, and where the court may not "see" the mental disability implications). ${ }^{83}$ The problems caused by this judicial myopia are even more alarming in light of the predictable aftermath of the Supreme Court's sterile and perfunctory adequacy of counsel standard set up in Strickland v. Washington ${ }^{84}$ : Most courts adhere to a minimalist reading of Strickland, ${ }^{85}$ resulting in a situation where Judge Bazelon's

commitment. Lessard v. Schmidt, 349 F. Supp. 1078, 1004 n. 22 (E.D. Wis. 1972), quoting testimony by Dr. David J. Vail, former medical director of the Minnesota Department of Public Welfare.

78470 U.S. 68,74 (1985).

${ }^{79}$ See generally, 3 M. Perlin, supra note 5, \$17.17, at 550-52, and id. at 157-58 (1991 pocket part) (citing cases).

${ }^{80}$ Ake, 470 U.S. at 80.

${ }^{81}$ See supra note 47 (citing the few cases in which Ake has been considered in a civil context).

${ }^{82}$ On the implementation of Ake in general, see Casey \& Keilitz, An Evaluation of Mental Health Expert Assistance Provided to Indigent Criminal Defendants: Organization, Administration, and Fiscal Management, 34 N.Y.L. Sch. L. Rev. 19 (1989). On the related ethical implications of Ake, see Appelbaum, In the Wake of Ake: The Ethics of Expert Testimony in an Advocate's World, 15 Bull. Am. Acad. Psychiatry \& L. 15 (1987); Rachlin, From Impartial Expert to Adversary in the Wake of Ake, 16 Bull. Am. Acad. Psychiatry \& L. 25 (1985).

${ }^{83}$ See e.g., Easing the Trials of Trial-Disabled Defendants: Competency Assistance Topic of New NCSC Study, NCSC Report, Vol. 15, \#7 (July 1988), at 1,3.

${ }^{84} 466$ U.S. 668 (1984). Under Strickland, there is no constitutional violation if counsel provides "reasonably effective assistance" to be measured objectively by "prevailing professional norms." Id. at 687-88; see generally, Perlin, The Supreme Court, the Mentally Disabled Criminal Defendant, Psychiatric Testimony in Death Penalty Cases, and the Power of Symbolism: Dulling the Ake in Barefoot's Achilles Heel, 3 N.Y.L. Sch. Hum. Rts. Ann. 91 (1985) (discussing Strickland in this context).

${ }^{85}$ See cases cited in 2 M. Perlin, supra note $5, \S 8.30$, at 845 n. 617 , and $i d$. at 132 (1991 pocket part). 
worst fantasy-of assigned counsel who are little more than "walking violations of the Sixth Amendment" countenanced in criminal cases involving mental status defenses (even in death penalty cases), ${ }^{87}$ there is no realistic chance of expecting serious scrutiny in civil cases. ${ }^{88}$

\section{The Limited Role of $P \& A$ 's}

While the passage of the $\mathrm{P} \& \mathrm{~A} \mathrm{Act}{ }^{89}$ has resulted in the provision of "needed rights enforcement services" for certain mentally disabled persons, ${ }^{90}$ this legislation is not a panacea for the underlying problems. Although the act is a major positive step in the right direction, ${ }^{91}$ the $\mathrm{P} \& \mathrm{~A}$ statute is not a palliative for all of the counsel adequacy problems discussed in this paper.

The legislative history of the Act specifies that it was not Congress's intention

to authorize P\&As to regularly provide assistance at commitment hearings. ${ }^{92}$ The Act was conceived of as a mechanism to prevent institutional neglect and abuse, and P\&A programs are neither able nor expected to redress all commitment issues. ${ }^{93}$ Further, NIMH policy directives stipulate that P\&A money should gen-

${ }^{86}$ Bazelon, The Defective Assistance of Counsel, 42 U. Cin. L. Rev. 1, 2 (1973), as quoted in Brown v. McGarr, 774 F. 2d 777, 783 (7th Cir. 1985).

${ }^{87}$ For a particularly shocking example, see Alvord v. Wainwright, 469 U.S. 956 (1984) (Marshall, J., dissenting from denial of grant of certiorari), discussed in $2 \mathrm{M}$. Perlin, supra note 5, $\$ 8.30$, at $848 \mathrm{n}$. 637. For an excellent overview of all issues, see Klein, The Relationship of the Court and Defense Counsel: The Impact of Competent Representation and Proposals for Reform, 29 B.C. L. Rev. 531 (1988).

${ }^{88}$ Since Strickland, only a handful of cases have considered effectiveness of counsel standards in the context of civil commitment cases. See e.g., Jones v. State, 477 N.E. 2d 353, 357-59 (Ind. Ct. App. 1985) (rejecting civil patient's Strickland challenge); In re Dibley, 400 N.W. 2 d 186 (Minn. Ct. App. 1987) (rejecting similar ineffectiveness claim on grounds of no prejudice; Strickland not cited); compare Matter of Pima Cty. Mental Health Serv., 157 Ariz. 314, 757 P. 2d 118 (Ct. App. 1988) (allegation of ineffective assistance of counsel at commitment hearing required evidentiary hearing). I consider the implications of Strickland for mentally disabled persons in danger of becoming homeless in Perlin, supra note 9, at 126-27.

${ }^{89}$ See 42 U.S.C. $\$ \$ 10801$ et seq. (Supp. 1988); see generally, Harvey \& Decker, Protection \& Advocacy for Persons With Mental Illness: A Resource for Rights Enforcement, 14 Law \& Psychology. Rev. 211 (1990); 2 M. Perlin, supra note 13, \$8.16.

${ }^{90}$ Harvey \& Decker, supra note 89, at 220.

${ }^{91}$ See 2 M. Perlin, supra note 5, Comment to $\$ 8.16$, at 799-800 (P\&A expansion "will inevitably have a significant effect on the quality and quantity of advocacy services" made available to institutionalized mentally disabled persons) (emphasis in original). Compare Sen. Rep. No. 99-109, reprinted in 1986 U.S. Code Cong. \& Admin. News 361, 1375 (P\&A Act will "ensur[e] protective rights to all mentally ill persons residing in institutions throughout this country" (additional view by Senator Kerry et al.) (emphasis added).

${ }^{92}$ Report to Accompany S. 2392, Senate Committee on Labor \& Human Resources, S. Rpt. No. $100-454$ (August 1988), at 7. When not used to describe the congressional act, the adjective "P\&A" refers to programs and offices established under the Act.

${ }^{93}$ (Personal communication, Natalie Reatig, Director, Protection and Advocacy Program, Division of Education and Service Systems Liaison, NIMH, February 8, 1991). 
erally not be used for civil commitment hearings, as this is considered a state function that should not be supplanted by the federally funded program. ${ }^{94}$

Also, each state is free to establish its own priorities, within the constraints of the federal statute and policy guidelines, in determining substantive areas of service provision concentration. ${ }^{95}$ Some jurisdictions receive only modest funding under the Act. ${ }^{96}$ Finally, recent P\&A statistics reflect the tiny percentage of P\&A resources that go to litigation in contested cases; moreover, the litigation done by P\&A offices is not evenly proportioned across jurisdictions. ${ }^{97}$ In short, the P\&As cannot be relied upon to solve the underlying problems.

\section{The Increased Complexity of Mental Disability Law}

The need for counsel has also increased as the substance of mental disability law has become more complicated. ${ }^{98}$ The retrenchment in the federal courts that has resulted in a judiciary that is far more hostile to all sorts of civil rights claims ${ }^{99}$ has forced litigators seeking to establish new rights to look to other forums: to administrative arenas and to state courts (arguing under state constitutions). ${ }^{100}$ As

94 The NIMH Protection and Advocacy Program: Evolving Policy Guidelines 5 (January 1, 1991), and see id. (listing limited situations in which P\&As can represent individuals at commitment hearings); see also, 42 U.S.C. \$10821(1) (Supp. 1988) ("non-supplanting"' provision of P\&A Act).

${ }^{95}$ See e.g., 42 U.S.C. $\$ 10805$ (a)(6) (role of Advisory Council in priority setting); id. $\$ 10805$ (c)(1)(A), $\$ 10805(\mathrm{c})(2)(B)$ (role of governing authority in setting priorities with Advisory Council).

${ }^{96}$ Several states received only a minimum allotment of $\$ 152,000$ in fiscal year 1989 for all P\&A services for mentally ill clients. See P\&A Report, supra note 61 , at 3.

${ }^{97}$ See Harvey \& Decker, supra note 89 , at 218 (in fiscal year 1988 , only $1 \&$ of all client problems resulted in actual litigation). This statistic, of course, is susceptible to multiple interpretations; it may be that it also reflects P\&A programs' success in resolving disputes without the need for litigation.

On the lack of proportionality in litigation, see P\&A Report, supra note 61 , at 59-60, Table 8. A sutdy of the P\&A statistics also suggests that litigation is generally more likely to occur in those states where vigorous mental disability advocacy programs predated P\&A passage; e.g., New York, New Jersey, Texas, Massachusetts. For a state-by-state analysis of the different ways counsel had been provided to mentally disabled individuals prior to the P\&A Act, see American Bar Ass'n, Comm'n on the Mentally Disabled, Mental Health Advocacy Services Report: Final (undated).

${ }^{98}$ Recently enacted federal statutes now provide new substantive rights for the mentally disabled to be free from discrimination in matters of housing, employment, and access to health services and entitlements. See e.g., P.L. 101-366, 104 Stat. 327 (Americans With Disabilities Act); 42 U.S.C. $\$ 3602$ (1990) (Fair Housing Act Amendments)). Without the presence of adequate counsel, these statues may perpetuate the illusion that the mentally disabled have certain substantive rights, but leave them with no means for seeking the effectuation of those rights. See generally, Bellow \& Kettleson, From Ethics to Politics: Confronting Scarcity and Fairness in Public Interest Practice, 58 B.U. L. Rev. 337 (1978). For a related inquiry, see H. D. Graham, The Civil Rights Era: Origins and Development of National Policy 63 (1990) (discussing political implications of President Kennedy's failure to desegregate federally subsidized housing with "a mere presidential penstroke"); see also id. at 455 (political implications of gap "between agreement with abstract principles and steps to implement the principles").

${ }_{100}^{99}$ See Perlin, supra note 10 , at $136-37$.

${ }^{100}$ See generally, Perlin, State Constitutions and Statutes as Sources of Rights for the Mentally Disabled: The Last Frontier? 20 Loy. L.A. L. Rev. 1249 (1987). The significance of the emergence 
a result, mental disability lawyers need to continually exhibit more familiarity with a far wider variety of substantive and procedural doctrines than they might have had to master in the mid-1970s (when it appeared that the civil rights of patients and expatients would continue to expand indefinitely). ${ }^{101}$

\section{Changes in Social Climate}

The external social climate has also changed. Though the public expressed considerable sympathy to and support of lawyers involved in exposes of "shock the conscience" facilities in the early $1970 \mathrm{~s},{ }^{102}$ times have changed. The more recent combination of (a) financial austerity, (b) years of socially acceptable mean-spiritedness toward the socially disadvantaged, ${ }^{103}$ (c) the collapse of many supportive social service systems, ${ }^{104}$ (d) the "swing of the pendulum" 105 that has led many states to once again loosen both substantive commitment criteria and procedural due process protections (resulting in new increases in involuntary commitment caseloads) ${ }^{106}$ and (e) a general weariness with the whole range of social problems that seemed to flow from the early civil rights movement in this

of state constitutional remedies in this context of the development of mental disability law is considered in Wexler, supra note 57.

101 Three examples should be illustrative. For the past several years, the scope of a patient's right to refuse treatment has developed in significantly different ways in the state and federal court systems, and it is critical that counsel understand the differences both in doctrine and in the underlying rationales. See generally, Perlin, Are Courts Competent To Decide Competency Questions? Stripping the Facade From United States v. Charters, 38 U. Kan. L. Rev. 957 (1990).

In a completely different context, patients' counsel-traditionally accustomed to filing suits seeking to vindicate their clients' right to refuse medication-are now structuring litigation, seeking to vindicate the right to receive certain medications, most notably clozapine. See Edward K. et al v. White, Civil Action No. 88-3358 (E.D. Pa. 1990) (seeking Clozaril treatment for all class members residing at Pennsylvania state psychiatric hospital) (plaintiffs represented by Disabilities Law Project); see generally, Winslow, Courts Consider Schizophrenia Drug's Access, Wall. St. J., Oct. 5, 1990, at B1 (discussing Clozaril litigation); on the advocacy issues, see P. Margulies, "A Case Study of the Cognitive Psychology of Law Reform: Mental Health Advocates' Ambivalence About New Schizophrenia Medication," (paper delivered at the Association of American Law School's Section on Law and Mental Disability's annual meeting, Washington, DC, January 1991); see also, 23 States File Antitrust Suit Against Sandoz, Psychiat. News (Jan. 18, 1991), at 1, 6-7. Finally, the conflict between the implementation of the least restrictive alternative and the imposition of tort liability for premature releases from inpatient facilities has caused advocates to weigh the question of whether courts should be involved in release decision making in all cases of patients involuntarily committed following a finding of dangerousness to others. See Perlin, supra note 10, at 126 n. 380 (discussing debate held at annual American Academy of Psychiatry and Law Conference, October 1990, on this issue).

${ }^{102}$ See $1 \mathrm{M}$. Perlin, supra note $5, \$ 1.03$, at $7-8$ (discussing public awareness of institutional conditions as an animating force in the growth of mental disability law).

${ }^{103}$ Perlin, supra note 10 , at 64-67.

104 Id . at $74-80$.

${ }^{105}$ The pendulum metaphor is employed, inter alia, in Durham \& LaFond, supra note 30, at 398; Myers, Involuntary Civil Commitment of the Mentally Ill: A System in Need of Change, 29 Vill. L. Rev. 367, 379 (1983-84); Shuman, Innovative Statutory Approaches to Civil Commitment: An Overview and Critique, 13 Law, Med. \& Health Care 284, 286 (1985).

106 See e.g., Durham \& LaFond, supra note 30, at 444. 
area (focusing on the perceived linkage between deinstitutionalization and homelessness), ${ }^{107}$ has created a new climate where patients' rights lawyers are seen as "the enemy." 108 Professor Jan Costello's anecdotal discussion of the paradigmatic cocktail party - at which she, as a former patients' rights lawyer, is blamed by other partygoers as the primary cause of homelessness ${ }^{109}$-reflects this change in political and social climate. In short, mental disability lawyers are working in a more hostile and coercive environment, an environment that definitionally heightens the demand for a cadre of well-trained and sensitive counsel to provide representation to the population in question. ${ }^{110}$

\section{Other Moral, Social, and Political Issues}

Adequate counsel is also needed to deal with other collateral moral, social, and political issues that, to an important degree, affect legal and public decision making in this area. ${ }^{111}$ If such issues as the "dilemma of the moral clinician," 112 the impact of pretextuality on the mental disability trial process, ${ }^{113}$ the way that the use of "ordinary common sense" drives decision making by judges and jurors alike in such cases, ${ }^{114}$ and the pervasiveness of heuristic biases in such decision making, ${ }^{115}$ are not confronted by counsel, it is likely that the pervasive cognitive and behavioral biases that infect decision making in this area will continue unnoticed and unabated. Finally, the recent interest demonstrated by scholars in "ther-

${ }^{107}$ Perlin, supra note 10 , at 93-107.

${ }^{108}$ See e.g., E. F. Torrey, supra note 4, at 156-59; see also, Lambert, Psychologists Back Koch Policy on Hospitalizing Homeless People, N.Y. Times, Sept. 1, 1987, at A1 (patients' rights lawyers called "crazies" by former NYC Mayor Ed Koch).

109 J. Costello, "Automony and the Homeless Mentally Ill: Rethinking Civil Commitment in the Aftermath of Deinstitutionalization," (paper presented at the annual meeting of the Association of American Law School's Section on Law and Mental Disability, San Francisco, CA, Jan. 1990), manuscript at 3 .

${ }^{110}$ For a helpful historical perspective, see Note, The New Public Interest Lawyers, 79 Yale L.J. 1069 (1970).

111 I consider these ideas in greater depth in, inter alia, Perlin, supra note 45; Perlin, supra note 55; Perlin, Psychodynamics and the Insanity Defense: "Ordinary Common Sense" and Heuristic Reasoning, 69 Neb. L. Rev. 3 (1990) (Ordinary Common Sense); and Perlin, Power Imbalances in Therapeutic and Forensic Relationships, 9 Behav. Sci. \& L. 111 (1991).

112 See e.g., Perlin, supra note 55, at 135-36. Here I consider evidence suggesting that, in response to legislative actions tightening involuntary civil commitment criteria, some forensic mental health professionals answered by suggesting that such mandates could be ignored if they conflicted with the witnesses' "moral judgment."

${ }^{113}$ Id. at 133-35. By this I mean that there is a dramatic tension between those areas in which courts accept dishonesty in certain subject-matter areas and those where they erect insurmountable barriers to guard against what they perceive as malingering, feigning, or otherwise misusing the legal system.

114 See e.g., Ordinary Common Sense, supra note 111, at 22-39. This concept is considered most carefully in Sherwin, Dialects and Dominance: A Study of Rhetorical Fields in Confessions, $136 \mathrm{U}$. Pa. L. Rev. 729 (1988).

115

Ordinary Common Sense, supra note 111, at 12-22. I refer here to the types of simplifying cognitive devices that frequently lead to distorted and systematically erroneous decisions through ignoring or misusing rationally useful information. See generally, Saks \& Kidd, Human Information Processing and Adjudication: Trial By Heuristics. 15 Law \& Soc'y Rev. 123 (1980-81). 
apeutic jurisprudence" should force all participants in the system to begin to critically weight the therapeutic (or antitherapeutic) effect of the mental disability system. ${ }^{116}$ Here, adequate counsel is needed to ensure consideration of the therapeutic potential inherent in mental disability litigation. It is not enough for a lawyer to simply argue that the Fourteenth Amendment demands a due process hearing prior to involuntary commitment; she also needs to have read, studied, and weighed the implications of Ensminger and Liguori's article raising the possibility that the civil commitment hearing has a distinct, but unexplored, therapeutic potential. ${ }^{117}$

In summary, the roles of counsel in the representation of the mentally disabled are multitextured and continually evolving. It is critical for systemic decision makers to acknowledge these roles, the historic shortcomings of sporadic counsel serving the population in question, and ways of attempting to solve some of the underlying problems.

\section{CONCLUSION}

I suggest the following recommendations as a modest means of beginning to come to grips with the issues discussed above:

1. Each jurisdiction should study carefully the way counsel is assigned, the quality of counsel, and the impact of counsel on the operation of the mental disability law system. This investigation should include such issues as when counsel is assigned, the availability of counsel for appellate review, who pays for counsel, and who selects those eligible to provide counsel. As part of this inquiry, the National Center for State Courts' Guidelines for Involuntary Commitment should be closely studied.

2. Each jurisdiction should make progress toward providing adequate, regularized, structured counsel to all mentally disabled individuals (and should carefully assess the way that counsel is provided to represent the hospital or state agency that generally take opposing positions). Training should be made available for all participants in the judicial decision-making system (including patients' counsel, hospital counsel, court administrators, and judges), and lists of trained lawyers should be maintained in each jurisdiction. ${ }^{118}$ Also, cooperative continuing education programs should be instituted for mental disability professionals to sensitize them to the legal issues involved.

3. Scholars should add this issue to their research agenda ${ }^{119}$ and should

${ }^{116}$ See Therapeutic Jurisprudence: The Law as a Therapeutic Agent (D. Wexler ed. 1990); Wexler, supra note 57.

117 Ensminger \& Liguori, The Therapeutic Significance of the Civil Commitment Hearing: An Unexplored Potential, 6. J. Psychiatry \& L. 5 (1978), reprinted in D. Wexler ed., supra note 116, at 245. For the full range of issues contemplated by Wexler in this context, see Wexler, An Introduction to Therapeutic Jurisprudence, in D. Wexler ed., supra note 116, at 3-20.

${ }^{118}$ Optimally, there should be some sort of linkages provided between this training and the law school curriculum.

119 Compare e.g., Keilitz, Researching and Reforming the Insanity Defense, 39 Rutgers L. Rev. 47 
consider new ways of assessing the quality of counsel and its impact on both the trial of cases involving the mentally disabled and the ultimate outcomes to the mentally disabled.

4. Litigators should carefully assess the way that Supreme Court cases like Strickland and Ake affect the role of counsel and should work on new and creative strategies (using forums other than federal court, if necessary) to best try to ensure that adequate counsel is made available to all mentally disabled litigants. ${ }^{120}$

5. Behavioral researchers should look critically at allegations that seek to scapegoat patients' rights lawyers as the true villains in the social drama being staged and try to evaluate the extent, if any, to which these charges have merit.

6. Law schools should devote more time, resources, and commitment both to the study of mental disability law as an academic discipline and to the special skills and "lawyering" issues involved in the representation of mentally disabled persons through specialized clinics and training programs.

Although this short list is far from a panacea, at the least it should force participants in the system to critically rethink their often-faulty assumptions about counsel and its provision in litigation involving mentally handicapped individuals. If that were to happen, then perhaps this area of the law would no longer be, in Appelbaum's poignant phrase, the "disfavored stepchild" of the legal process. ${ }^{121}$

(1987); Steadman, Mental Health Law and the Criminal Offender: Research Directions for the 120 S990's, 39 Rutgers L. Rev. 81 (1987).

Similarly, nonlitigator players in this arena need to become aware of the constitutional limitations imposed by cases such as Strickland and Ake's progeny and must be able to factor these limitations into their decision making. 121 Appelbaum, Civil Commitment from a Systems Perspective, this issue, 16 Law \& Hum. Behav.
$61-74$ (1991). 